\title{
THE USE OF THE MEDIUM OF INSTRUCTION IN PRIMARY CHINESE TEACHING: A CASE STUDY OF THE CONFUCIUS INSTITUTE AT V.N. KARAZIN KHARKIV NATIONAL UNIVERSITY
}

\author{
Xiao Chenyang (China)
}

When teaching Chinese overseas, the author finds that using the medium of instruction as an auxiliary teaching is an indispensable part in the process of international Chinese teaching, especially in overseas Chinese teaching classes. In addition, the level of foreign language of Chinese teachers abroad is different. For example, a large number of Chinese teachers who teach in the Russian-speaking areas do not fully master Russian, some Chinese teachers are not very good in English, neither. This article takes the teaching reality of the primary Chinese class in Ukraine as an example.

There are many benefits in using the medium of instruction, such as saving time, improving teaching efficiency, and getting closer to students. It is worth mentioning that it also helps learners better understand two different languages. At the same time Chinese teachers can use other languages in Chinese classes, but they cannot spend most of their teaching time on speaking foreign languages. We can not achieve "immersive" Chinese teaching at the current stage of overseas Chinese teaching, but we should input Chinese as much as possible to create the Chinese learning environment for students as much as possible, while reducing the impact of negative language transfer.

This paper combines teaching practice to summarize how many medium of instruction used in primary Chinese class can be beneficial to teaching, and also will analyze the correct timing of using medium of instruction, and how to use medium of instruction to better assist learning Chinese. At the same time, the author believes that when selecting and dispatching Chinese teachers, we should pay attention to the cultivation of Chinese teachers' language ability and teaching ability. The author believes that these measures will help reduce the negative influence of medium of instruction on students.

Key words: medium of instruction, teaching Chinese as a foreign language, Ukraine.

Сяо Ченьян. Використання мови викладання на початковому етапі навчання китайської мови: тематичне дослідження Інституту Конфуція у Харківському національному університеті імені В.Н. Каразіна. У центрі дослідження цієї статті аналіз практичного досвіду викладання китайської мови як іноземної в умовах позамовного середовища, який дозволяє зробити певні висновки про те, що використання мови-посередника дуже важливе і $є$ необхідним складником процесу навчання китайської мови як іноземної, особливо в навчанні інофонів за межами Китаю. У статті звертається увага на те, що викладачі китайської мови як іноземної на різному рівні володіють мовою-посередником. Автор наводить факти недостатнього володіння російською мовою значної кількості викладачів китайської мови як іноземної, що працюють в російськомовній аудиторії, й окремі факти недостатнього володіння англійською мовою-посередником. Дослідник відзначає, що проблема мови-посередника особливо актуальна на початковому етапі навчання в умовах

(C) Xiao Chenyang, 2019 
навчального простору України, а саме, в мережі Інститутів Конфуція та Інституту Конфуція університету В. Н. Каразіна, зокрема. У статті названо переваги використання мови-посередника, серед яких економія часу, підвищення якості навчання, сприяння формуванню білінгвізму у слухачів тощо. У статті також наводяться приклади використання інших мов-посередників, здебільшого європейських. Автор визначає важливість подальшого професійного розвитку вчителів китайської мови й наводить приклади щодо проведення посттренінгів для працюючих вчителів, які високо відгукувалися про знання, отримані під час спілкування 3 досвідченими фахівцями. У статті доводять, що не лише фактичне навчання мові, але й можливість продовжити професійний розвиток під час роботи покращить рівень викладання китайської мови.

Ключові слова: навчання китайської мови, середовище навчання, Україна.

Сяо Ченьян. Использование языка преподавания на начальном этапе обучения китайскому языку: тематическое исследование Института Конфуция в Харьковском национальном университете имени. В.Н. Каразина. В центре исследования данной статьи анализ практического опыта преподавания китайского языка как иностранного вне языковой среды, который позволяет сделать выводы о том, что использование языка-посредника очень важно и является необходимой составляющей процесса обучения китайскому языку как иностранному, особенно при обучении инофонов за пределами Китая. В статье также обращается внимание на то, что преподаватели китайского языка как иностранного владеют языком-посредником на разном уровне. Автор приводит факты недостаточного владения русским языком значительным количеством преподавателей китайского как иностранного, работающих в русскоязычной аудитории, и также отдельные факты недостаточного владения английским языком-посредником. Исследователь отмечает, что проблема использования языка-посредника особенно актуальна при преподавании китайского как иностранного на начальном этапе обучения в условиях образовательного пространства Украины, в частности, в сети Институтов Конфуция и Института Конфуция в университете В.Н. Каразина. Исследователь называет преимущества использования языка-посредника, такие как экономия учебного времени, повышение эффективности обучения, развитие билингвизма у обучаемых и т.д. Кроме того, в статье приводятся примеры ограниченного использования других языков, в большей мере европейских, в качестве языка-посредника на занятиях по китайскому языку как иностранному в неоднородной языковой среде Украины.

Ключевые слова: обучение китайскому языку, среда обучения, Украина.

The topicality of the research. Nowadays, more and more teachers are teaching Chinese abroad. Many foreign universities have begun to pay attention to Chinese. Some have set up Chinese courses at universities, and some have cooperated with China to run Confucius Institutes. These also happen in Ukraine. If you want to work as a Chinese teacher at the Confucius Institute, according to regulations, your major must be related to Chinese. You can also be a graduate of the Russian major, or a Chinese student studying in Ukraine. This has 
led to a situation in which many different languages may appear in the Ukrainian Chinese class. Therefore, this article would like to explore what the actual use of the medium of instruction is in the current Chinese teaching in Ukraine.

The degree of scientific research of the issue. First of all, what is the medium of instruction? The medium of instruction refers to the language that teachers use in second language teaching in addition to the target language, andit is mostly used in bilingual or multilingual classes, and are equally applicable in Chinese classes.

Secondly, why we must use the medium of instruction in the primary Chinese class? According to S. Krashen's language input hypothesis, in the process of second language and foreign language acquisition, if only input is not enough, it is necessary to provide the learner with "understandable input” [1].

Thirdly, many scholars have studied the subject of medium of instruction and put forward their views. For example, Wang Hanwei believes that we generally use the medium of instruction in the primary class, which includes the medium of instruction in the textbook and the classroom language used by the teacher [4]. Chen Xiajin discussed the use of medium of instruction in the teaching of Chinese as a starting point and in the primary stage. He believed that using medium of instruction for teaching in the primary stage can have a multiplier effect [2]. Zhang Wanjuan studied the second-level Chinese class as an object, and believed that the frequency and method of using the medium of instruction had a direct impact on the teaching effect [5].

Therefore, in summary, the medium of instruction referred to in this paper is a foreign language used by overseas Chinese teachers in the classroom to facilitate students' understanding, and the non-verbal behavior used by teachers.

The aim of the article. In the case we mentioned above, how do we use the medium of instruction to help us teach Chinese? The purpose of this study is when to use the medium of instruction, and howto use. In addition, the author also hopes to use this information to provide some useful information for the Chinese teaching.

Presentation of the main material. This article will combine the author's examples in the teaching of the Confucius Institute at Kharkov, Ukraine, to analyze the positive and negative effects of using mediumof 
instruction in this multilingual environment, and make recommendations based on these things. Details are as follows.

Positive effects of the medium of instruction.

1. Improve teaching efficiency.

The use of medium of instruction teaching can help to shorten the teacher's explanation time and students' understanding time, thus improving teaching efficiency. In the actual teaching, in order to save time, the medium of instruction can be used to explain the phonetic, the vocabulary, the grammar, the text and the practice.

For example, when teachers talk about the grammatical concept of "measure word", because there are similar concepts in Russian and English grammar, teachers can use those languages to explain.

2. Conducive to deepen the understanding of language.

Mr. Lyu Shuxiang pointed out that if you want to understand the Chinese language, you must compare it with non-Chinese [3]. If the teacher can compare the two languages and find the corresponding language materials for teaching, the teaching effect will be improved. This will effectively prevent students from having a negative transfer from their mother language or English.

For example, in phonetic teaching, the consonant " $t$ " of Chinese is similar to the consonant " $m$ " of Russian, but the " $d$ " of Chinese and the " $\partial$ " of Russian have the difference between unvoiced and voiced, which teachers can use to compare and explain.

3. Strengthen mutual understanding between teachers and students.

One of the functions of the medium of instruction is to help strengthen mutual understanding between teachers and students. Imaging if the student can't understand what the teacher is saying, he will be distracted, and lose interest in the course. Therefore, with the help of medium of instruction, students can integrate into this class, which will strengthen their learning motivation and will also benefit their future study.

Negative effects of the medium of instruction.

1. Unfavorable for establishing a language environment.

As we know, only the accumulation of quantity can achieve a qualitative leap. So if teachers explain all the things with the medium of instruction, the input of Chinese may not be enough, and it will make the students out of the Chinese learning environment. The result of this 
is that students will only recognize and read Chinese, but will not speak Chinese fluently.

2. It is not conducive to cultivate students to think in Chinese way.

Learning a language is also learning a way of thinking, learning how to use this language to communicate. For example, in the process of Chinese language teaching in Ukraine, the author finds that students always make mistakes in the use of adverbial modifier of time and place. The author believes that part of the reason for this problem is due to the influence of the student's mother tongue or the negative transfer from English, because in English or Russian, the words which mean time and place are usually post-positioned. The other part of the reason is that when the teacher speaks the medium of instruction, it will invisibly strengthen this negative influence.

For example:

I have run for 3 hours. I Я бегал 3 часа.

If teachers speak these kinds of sentences in the medium of instruction, and then ask students to translate it, generally they will get the following answer:

*我跑步了三个小 $\square$ 小时[wo p’aopu le sanko hsiaoshih].

And we know that the correct sentence should be "我跑厂三个 小时步" [wo p'ao le sanko hsiaoshih pu], in Chinese, we should place the adverbial modifier of time and place between the verb part and the object part. Obviously, this sentence is affected by the negative transfer from their mother tongue or English. The same example is "I am eating at the restaurant / Я ем в ресторане", and so on. Students usually make mistakes in it. Therefore, we say that the inappropriate use of medium of instruction is not conducive for the development of students.

3. Increase the difficulty of students' learning.

If the teachers' foreign language is not good, or the students' foreign language is not good, whatever the reason is, then it will lead to emotional filtering by students. Because they will feel that Chinese is difficult to understand, and the foreign language that the teacher speaks is also difficult to understand. This will be very tiring for some beginners. Especially for primary and secondary school students. Moreover, it will even have a bad influence on the image and quality of 
Chinese teachers. Therefore, we must pay attention to the use of medium of instruction.

However, how to use Chinese language to assist Chinese teaching, the following are some suggestions that the author has summarized based on the actual teaching.

1. Use medium of instruction moderately.

Based on the above-mentioned positive and negative effects of the medium of instruction, we can make a suggestion about how to use it moderately.

1) Use according to the language level of the students.

Firstly, if the student's Chinese proficiency is zero-based and even the Chinese "pinyin" has not been learned, teachers need to use more medium of instruction to help students build knowledge structure and guide students into the door of Chinese learning. And if the student already has some Chinese knowledge, for example, they have already passed the exam of HSK 2, and then the teacher needs to speak more Chinese in class.

Secondly, teachers who teach Chinese in the Russian-speaking area should learn more Russian. Because if the identity of the teaching objects is college students, then the teacher's use of English as a medium of instruction will not have much impact. But if the students are from primary or secondary school, or they have job, they may be influenced because they may not be so good at English. At this time, the author's suggestion is that the teacher can use translate some vocabulary or teaching language before class, this is a very effective way that the author thinks.

2) Use according to the teaching content.

Teachers need to change their teaching methods based on what they teach. For example, if the teacher is teaching vocabulary, the vocabulary can be divided into three categories. The first type can be represented by pictures, actions or objects. Such as "桌子 [chuotsi]", "跑 [p'ao]". The second category is to use translation to help understand. Such as "物理 [wuli]", "历史[lishih]". The third category can be explained in simple Chinese. Such as ""头顶[t'outing]" and "山 顶[shanting]", we can interpret these two words in combination with the "头[t'ou]" and "山 [shan]" we have learned before. Students will 
soon understand and deepen their impression on them. Obviously, we do not need to use the medium of instruction in the first and third category, but the medium of instruction in the second category will help us to teach.

3) Do not speak too fast.

If teachers are using the medium of instruction, they should speak slowly and clearly. Otherwise, as what we have mentioned in the negative effects, it will increase the difficulty of students' learning.

2. Use the medium of instruction accurately.

Teachers must pay attention to accuracy when using the medium of instruction, because inaccurate expression can lead to students' misunderstanding. Let's take an example. When the author took over a second-level Chinese class, author found that many students wrote a sentence with a problem that they misused the words “小时 [hsiaoshih]” and "点 [tien]". In Chinese, “3 小时 [hsiaoshih]” means “3 hours”, and “3 点 [tien] ”means “3 o'clock”. But in Russian, if we ignore the preposition, both of them are "3 часа". Therefore, many students like to use “我腄厂三点 [wo shuile san tian]” to show they have slept for 3 hours, but in fact, the sentence should be “我睡了三小 时 [wo shui le san hsiaoshih]”. If the teacher has emphasized this before, they can avoid this kind of problem.

3. Use the medium of instruction in right timing. The author has thought about this issue and believes that the medium of instruction can be used at the following timing.

1) It can be used to greet students.

If you greet the students in English or Russian before class, asking them about their study or life, it will increase the students' affection for you.

2) It can be used for classroom instruction and discipline management.

In the zero-based class, teachers can use the medium of instruction to say some classroom instructions, such as "Ready?", "Please raise your hand". You can also use the medium of instruction to say some jokes. This allows the student to feel that the teacher is communicating with them, and this will also attract the attention of the students in time to prevent them from distracting. 
However, as the level of students increases slowly, teachers need to reduce the use of medium of instruction in classroom instruction, because after a period of study, they can fully understand some of the teacher's instructions. Teachers can use this as a kind of training to train students to produce a "stimulus-response" to such instructions.

4. Pay attention to the mutual complementation between the target language and the medium of instruction.

1) Compare the similarities between the two languages.

Comparing the same points will make it easier for students to accept difficult concepts. For example, in Chinese, there are many measure words, but we know in Russian there are measure words, too. At this time, teachers use the Russian measure words' concept to explain, which will reduce the students' fear about it.

2) Compare the differences between the two languages.

There are differences between the two languages, and language comparisons can avoid bias. For another example, there are two basic words “不 $[\mathrm{pu}]$ ” and “没 [mei]” in Chinese. “不 [pu]” means subjectively negating one thing, and “没 [mei]” means that for some objective reasons, there is no such thing. But if you use English to translate, the two words are "no". Many beginners that author came across often make mistakes in this issue. The reason is that in their previous Chinese learning process, this problem was not compared. They simply rely on translation software to translate these words, and then they form a bias.

5. Suggestions for cultivating Chinese teachers.

The author believes that we also need to pay attention to the cultivation of Chinese teachers. Because as mentioned earlier, Chinese teachers who teach in the Russian-speaking areas can graduate from Chinese-related majors or graduate from Russian-related majors. However, the problem is that students of Chinese-related majors may not be good at Russian, and students who graduate from Russianrelated majors may likely to lack professional Chinese knowledge and teaching skills.

The author thinks that there are two ways to solve the problem.

1) Optimize the training program for international Chinese teachers.

At present, many universities in China have begun to offer Russian, Spanish and other foreign language courses to students who study on 
Chinese-related majors to cultivate international Chinese teachers. The author believes that such measures should be promoted and popularized; help Chinese teachers better understand the language system of their future teaching objects.

2) Strengthen the training of on-the-job teachers.

The author feels that both the pre-job training and post-training are very important. Pre-job training will help teachers learn more about the teaching skills and students' characteristics of Ukraine, and will also teach teachers to speak Russian. The post-training will help teachers learn from each other. In the past two years, Chinese teachers in Ukraine have received the post-training. Through interviews, the author has learned that the post-training has helped teachers a lot.

Conclusion. In summary, the use of medium of instruction in the primary Chinese language teaching phase is an inevitable problem, but we must pay attention to the amount of use and timing of use, to be targeted, to ensure the accuracy of the medium of instruction we use; and we need to pay attention to contrastive language, and the similarity and difference between languages, too. We can also start from training teachers to optimize our teachers. Finally, the author hopes that some of the opinions and insights in this paper can provide some reference value for the study of medium of instruction.

Perspectives of further research. The author thinks that this aspect of research in the future can focus on the comparative study of Chinese and other languages, because it can help us enrich the study of Chinese language. On the other hand, the author hopes there could be more real teaching case records, so that we can better propose teaching suggestions based on these to improve the effectiveness of Chinese teaching.

\section{LITERATURE}

1. Krashen S.D. Principles and practice in second language learning and acquisition. Oxford: Pergamon, 1982. P. 21.

2. 陈夏瑾.浅谈零起点对外汉语教学中媒介语的使用.现代语文（学术综 合版, 2013. 03. P. 84-85.

3. 吕叔湘.通过对比研究语法. 语言教学与研究, 1992. 02. P. 4.

4. 王汉卫.对外汉语教材中的媒介语问题适说. 世界汉语教学, 2007. 02. P. 111-117. 
5. 张万娟.对外汉语课堂教学中媒介语使用情况调查研究-以兰州理工大 学对外汉语课堂教学为例.兰州大学, 2016. P. 3 .

\section{REFERENCES}

Ch'en, Hsiachin. (2013). Ch'ient'an ling ch'itian tuiwai hanyüchiaohsüehchung meichiehyüte shihyung [On the Use of Medium of instruction in the Teaching of Chinese as a Foreign Language in the Beginning]. Hsientai yüwen. Hsüehshutsungho pan [Modern Language. Academic Comprehensive Edition], 03, pp. 84-85 [in Chinese].

Krashen, S.D. (1982). Principles and practice in second language learning and acquisition. Oxford: Pergamon, p. 21 [in English].

Lü, Shuhsiang. (1992). T’ungkuo tuipi yenchiu yüfa [Through comparative study of grammar]. Yüyen chiaohsüeh yü yenchiu [Language Teaching and Research], 02, p. 4 [in Chinese].

Wang, Hanwei. (2007). Tuiwai hanyüchiaots'ai chung te meichiehyü went'i shihshuo [The problem of medium of instruction in Chinese textbooks for foreigners is appropriate]. Shihchiehhanyüchiaohsüeh [World Chinese Teaching], 02, pp. 111-117 [in Chinese].

Chang, Wanchüan. (2016). Tuiwai hanyü k’ot'ang chiaohsüehchung meichiehyü shihyung ch'ingk'uang tiaoch'a yenchfiu - iLanchoulikung tahsüeh tuiwai hanyük'ot'ang chiaohsüeh weili [Study on the Use of Medium of Instruction in the Teaching of Chinese as a Foreign Language Taking Lanzhou University of Technology as an Example of Teaching Chinese as a Foreign Language]. Lanzhou University, p. 3 [in Chinese].

Стаття надійшла до редакиії: 15.02.2019

Сяо Ченьян, викладач китайської мови в Інституті Конфуція Харківського національного університету імені В.Н. Каразіна (61022, Харків, майдан Свободи, 6); e-mail: xiangchang27@126.com; orcid: https://orcid.org/0000-0003-2692-5397.

Сяо Ченьян, преподаватель китайского языка в Институте Конфуция Харьковского национального университета имени В.Н. Каразина (61022, Харьков, площадь Свободы, 6); e-mail: xiangchang27@126.com; orcid: https://orcid.org/0000-0003-2692-5397.

Chenyang Xiao, Chinese Teacher, Confucius Institute, V.N. Karazin Kharkiv National University (61022, Kharkiv, 6 Svoboda Square); e-mail: xiangchang27@126.com; orcid: https://orcid.org/0000-0003-2692-5397. 